OPEN ACCESS

Edited by:

Johanna Sjöstedt,

Lund University, Sweden

Reviewed by:

Norman B. Nelson,

University of California,

Santa Barbara, United States

Laodong Guo,

University of Wisconsin-Milwaukee,

United States

*Correspondence:

Yuko Omori

omori.yuko.ft@u.tsukuba.ac.jp

Specialty section:

This article was submitted to

Aquatic Microbiology,

a section of the journal

Frontiers in Marine Science

Received: 30 July 2020

Accepted: 15 October 2020

Published: 05 November 2020

Citation:

Omori Y, Saeki A, Wada S,

Inagaki $Y$ and Hama T (2020)

Experimental Analysis of Diurnal Variations in Humic-Like Fluorescent Dissolved Organic Matter in Surface Seawater. Front. Mar. Sci. 7:589064. doi: 10.3389/fmars.2020.589064

\section{Experimental Analysis of Diurnal Variations in Humic-Like Fluorescent Dissolved Organic Matter in Surface Seawater}

\author{
Yuko Omori ${ }^{1 *}$, Akira Saeki², Shigeki Wada ${ }^{3}$, Yuji Inagaki ${ }^{4}$ and Takeo Hama ${ }^{1,5}$ \\ ${ }^{1}$ Faculty of Life and Environmental Sciences, University of Tsukuba, Tsukuba, Japan, ${ }^{2}$ Graduate School of Life \\ and Environmental Sciences, University of Tsukuba, Tsukuba, Japan, ${ }^{3}$ Shimoda Marine Research Center, University \\ of Tsukuba, Shimoda, Japan, ${ }^{4}$ Center for Computational Sciences, University of Tsukuba, Tsukuba, Japan, ${ }^{5}$ Faculty \\ of Economics, Dokkyo University, Souka, Japan
}

Humic-like fluorescent dissolved organic matter (FDOM) has been widely used as tracers for bio-refractory dissolved organic matter (RDOM) to understand its dynamics in the oceans. Vertical distributions of humic-like FDOM are controlled by microbial production in the ocean interiors and photobleaching in surface layers. Although humiclike FDOM is expected to be actively produced in surface layers with high bacterial activity, its production in surface seawater is not well understood. To examine the diurnal variations in humic-like FDOM due to microbial production and photobleaching in surface seawater, we conducted seven experiments from night to day using surface seawater in the subtropical Pacific and coastal regions. Parallel factor analysis (PARAFAC) determined that FDOM in the incubated seawater was composed of three components: two types of humic-like FDOM and a protein-like FDOM. The fluorescence intensity of humic-like FDOM increased to $104.0 \pm 2.5 \%$ of the initial intensity during the night and decreased to $101.2 \pm 2.5 \%$ under sunlight exposure during the day. Conversely, its intensity significantly increased to $114.0 \pm 2.7 \%$ under dark conditions during the day. The turnover rates of humic-like FDOM by the increase and decrease in its intensity were estimated to be 0.14 and 0.11 day $^{-1}$, respectively. These comparable turnover rates indicated that the production and photobleaching of humic-like FDOM were almost in equilibrium in the surface layer, with a low level of humic-like FDOM. Linear correlations between the intensity of humic-like FDOM and concentrations of dissolved oxygen (DO) in all experiments under dark conditions indicated that humiclike FDOM were produced as the by-products of microbial respiration processes in the surface seawater. Using global bacterial respiration rates, the net production rate of humic-like FDOM in the global photic layer was estimated as 4.2-5.5 × $10^{17}$ R.U. year $^{-1}$, contributing to $75 \%$ of its production in the entire ocean.

Keywords: fluorescent dissolved organic matter, PARAFAC, microbial production, photobleaching, surface seawater

Abbreviations: AOU, apparent oxygen utilization; DAPI, 40,6-diamidino-2-phenylindole; EEMs, excitation emission matrices; FDOM, fluorescent DOM; LMM, linear mixed model; OTU, operational taxonomic unit; PAR, photosynthetically active radiation; PARAFAC, parallel factor analysis; RDOM, refractory DOM; SE, standard error. 


\section{INTRODUCTION}

Marine dissolved organic matter (DOM) constitutes one of the largest pools of reduced carbon on the Earth's surface, containing $662 \mathrm{Pg} \mathrm{C}$, similar to atmospheric $\mathrm{CO}_{2}$ (Hansell et al., 2009). The ultimate source of DOM in the ocean is the photosynthetic production of phytoplankton, and the major DOM sink is the respiration by marine bacterial planktons (Carlson and Hansell, 2015). The stability of DOM against microbial degradation is important for elucidating its dynamics in marine biogeochemical cycle. Labile fraction against microbial degradation is a minor component but plays an important role as a substrate for bacterial growth (Benner and Amon, 2015). Conversely, more than 90\% of DOM is resistant to microbial degradation and has been estimated to remain in the ocean for many years, which is referred to as RDOM (Bauer et al., 1992; Hansell, 2013).

In the surface layer of the ocean, the behavior of DOM is highly complicated. Biological activities, including photosynthesis, produce a wide variety of DOM (Carlson and Hansell, 2015). The labile fraction of DOM is rapidly decomposed by bacteria, where semi-labile DOM and RDOM are produced as the by-products of bacterial metabolism (Benner and Herndl, 2011). Transformation from labile to RDOM by the bacteria has attracted attention as one of the key processes of accumulating DOM pool as microbial carbon pump (Jiao et al., 2010; Zhang et al., 2018). Concomitant with the microbial activity, DOM undergoes photochemical reaction under sunlight irradiation (Mopper et al., 2015). However, the quantitative and qualitative changes taking place in the DOM in the surface layer due to microbial activity and photochemical reaction are difficult to understand because DOM is a mixture of many unidentified organic compounds (Dittmar and Paeng, 2009).

The FDOM is widely used as a tracer to understand the origin and behavior of organic components (Stedmon and Nelson, 2015). The measurement of excitation emission matrices (EEMs) data and PARAFAC facilitated the identification of multiple components of FDOM (Stedmon et al., 2003; Stedmon and Bro, 2008). Marine FDOM is generally composed of protein- and humic-like components (Coble, 1996). The levels of protein-like components have been found to be high in the surface layer, decreasing with depth (e.g., Yamashita and Tanoue, 2008; Jørgensen et al., 2011; Catalá et al., 2015) and have been found to exponentially decrease within $24 \mathrm{~h}$ during microbial dark incubation in the Atlantic Ocean (Lønborg et al., 2015), which implies that the protein-like components are a biologically reactive fraction in the DOM. The levels of humiclike components have been found to be low in the surface layer and increase with depth in the pelagic ocean. The positive correlation between the fluorescence intensity of humic-like components and AOU in deep oceans indicates that these are produced in situ through the microbial oxidation of organic matter (Hayase and Shinozuka, 1995; Yamashita and Tanoue, 2008; Omori et al., 2010; Jørgensen et al., 2011; Catalá et al., 2015). The bacterial production of humic-like components has been demonstrated to be the by-products of bacterial culture experiments (Kramer and Herndl, 2004; Shimotori et al., 2009, 2012; Goto et al., 2017; Arai et al., 2018).
As humic-like components are sensitive to photoirradiation with continuing low levels in the surface layer, photodegradation of fluorophore (photobleaching) has been considered as one of the most important factors controlling their dynamics in the surface layer (Omori et al., 2010, 2015; Jørgensen et al., 2011; Timko et al., 2015). However, little information is available on the production of humic-like components in the surface layer. Incubation experiments under dark conditions using surface seawater demonstrated the short-term production of humic-like FDOM with positive relationships between its rate of increase and the respiration rate of bacteria (Nieto-Cid et al., 2006) and between its increase and bacterial uptake of dissolved organic nitrogen (Lønborg et al., 2015). They suggested that humiclike FDOM is produced through bacterial metabolic activity in the surface as well as deep layers. Considering that the microbial biomass and its activity in the ocean surface are highest throughout the water column (Nagata et al., 2000; Kirchman, 2008), the FDOM production via bacterial metabolites in the surface layer is accordingly expected to be active. It has been speculated that humic-like FDOM is constantly produced by microbial activity at the surface of the ocean, although its fluorescence intensity is always low due to its rapid disappearance by photobleaching during the day. Therefore, a diurnal variation in humic-like FDOM is expected due to an increase in FDOM during the night and a decrease due to photobleaching during the day, although this has never been clearly assessed.

In this study, we conducted 1-day incubation experiments using surface seawater collected from the subtropical Pacific, coastal, and bay areas. The 1-day incubations began at sunset and changes in FDOM and dissolved oxygen (DO) concentration during the night and day were evaluated to demonstrate the diurnal variations in FDOM and relationship between FDOM production and bacterial activity.

\section{MATERIALS AND METHODS}

\section{Sampling}

The 1-day experiments were conducted using surface seawaters collected from three sites: subtropical North Pacific at $32^{\circ} 19^{\prime}$ $\mathrm{N}, 144^{\circ} 32^{\prime} \mathrm{E}$ aboard $R / V$ Shinseimaru in July 2016, coastal area at $34^{\circ} 40^{\prime} \mathrm{N}, 138^{\circ} 56^{\prime} \mathrm{E}$ in Shimoda, Shizuoka, Japan in August 2016 and April 2018, and bay area at $35^{\circ} 08^{\prime} \mathrm{N}, 139^{\circ}$ $37^{\prime}$ E in Misaki, Kanagawa, Japan in September 2017 (Table 1). For these experiments at each site, we collected surface seawater with a plastic bucket and transferred it to two acid-cleaned polycarbonate bottles $(20 \mathrm{~L})$. The 1-day experiment began on the sampling day using the seawater in one bottle, termed as "natural" seawater. Nutrients $\left(\mathrm{NaNO}_{3}\right.$ and $\mathrm{KH}_{2} \mathrm{PO}_{4}$ : 11.6 and $1.49 \mu \mathrm{M}$ of final concentrations) were added to the seawater sample in another bottle, which was subsequently incubated for 3 days under natural sunlight in an aquarium with running seawater to maintain the ambient temperature for increasing microbial biomass, including bacteria. This incubated sample was termed as "nutrient-added" seawater in the experiments. Experiment at Shimoda in April 2018 was conducted using only natural seawater. 
TABLE 1 | Biological and chemical properties of surface seawater samples at the beginning of each experiment.

\begin{tabular}{|c|c|c|c|c|c|c|c|c|c|}
\hline Site & Incubation & Nutrient $^{a}$ & $\begin{array}{c}\text { Bacteria cell } \\
\text { number }\left[\times 10^{6}\right. \\
\left.\text { cells } \mathrm{mL}^{-1}\right]\end{array}$ & $\begin{array}{c}\text { Phytoplankton } \\
\text { cell number } \\
{\left[\times 10^{4} \text { cells } \mathrm{mL}^{-1}\right]}\end{array}$ & $\begin{array}{l}\text { DOC } \\
{[\mu \mathrm{M}]}\end{array}$ & $\begin{array}{c}\mathrm{NO}_{2}+\mathrm{NO}_{3} \\
{[\mu \mathrm{M}]}\end{array}$ & $\begin{array}{l}\mathrm{PO}_{4} \\
{[\mu \mathrm{M}]}\end{array}$ & $\begin{array}{c}\text { PAR } \\
{\left[\mathrm{mol} \mathrm{m}^{-2}\right.} \\
\left.\text { day }^{-1}\right]\end{array}$ & $\begin{array}{c}\text { Water } \\
\text { temperature } \\
{\left[{ }^{\circ} \mathbf{C}\right]}\end{array}$ \\
\hline \multirow{2}{*}{$\begin{array}{l}\text { Subtropical } \\
\text { Pacific Ocean }\end{array}$} & \multirow[t]{2}{*}{2016 Jul } & No add & $0.90(0.03)$ & $0.38(0.06)$ & $72.6(0.9)$ & n.d. & n.d. & 64.5 & 27.5 \\
\hline & & Add & $1.2(0.04)$ & $0.89(0.12)$ & $81.8(0.7)$ & n.d. & n.d. & 45.8 & 26.0 \\
\hline \multirow[t]{3}{*}{ Shimoda } & \multirow[t]{2}{*}{2016 Aug } & No add & $0.57(0.05)$ & 17 (1.6) & $86.5(1.3)$ & n.d. & n.d. & 22.0 & 27.0 \\
\hline & & Add & $1.6(0.02)$ & $5.2(0.10)$ & $108.8(0.7)$ & n.d. & n.d. & 24.2 & 27.0 \\
\hline & 2018 Apr & No add & $1.5(0.02)$ & $1.5(0.04)$ & $85.4(1.2)$ & $1.2(0.00)$ & $0.20(0.00)$ & 21.4 & 25.0 \\
\hline \multirow[t]{2}{*}{ Misaki } & \multirow[t]{2}{*}{2017 Sep } & No add & $2.6(0.10)$ & $2.6(0.03)$ & $104.8(3.1)$ & $4.8(0.01)$ & $0.65(0.01)$ & 19.4 & 27.5 \\
\hline & & Add & $1.1(0.06)$ & $20(0.17)$ & $106.4(0.7)$ & $5.4(0.01)$ & $0.30(0.00)$ & 21.5 & 27.5 \\
\hline
\end{tabular}

a "No add" and "Add" of nutrient mean the natural seawater and the nutrient added seawater, respectively.

SEs are shown in parentheses.

\section{1-Day Experiments}

Seawater samples in the $20-\mathrm{L}$ polycarbonate bottles were gently transferred into 12 Winkler bottles (approximately $100 \mathrm{~mL}$ ) without air and 12 quartz bottles $(200 \mathrm{~mL})$. The 1-day experiments began at sunset and were completed at sunset after $24 \mathrm{~h}$. Triplicate subsamples in Winkler and quartz bottles were collected at the beginning of the experiments ("beginning" samples: B). The remaining nine bottles were incubated overnight in an aquarium with running seawater. Afterward, the triplicate subsamples were collected at sunrise, termed as "morning" samples (M). Of the remaining six bottles, three were successively exposed to sunlight radiation and termed as "daytime light" samples (DL), while the other three bottles were wrapped in aluminum foils and cultured under dark condition, termed as "daytime dark" samples (DD). These six bottles were collected at sunset at the end of the experiments. During the daytime incubations, solar irradiances of PAR (400-700 nm) were monitored by PAR sensors (SQ100, Apogee). After collecting the Winkler bottles, the samples were immediately fixed for the measurements of concentrations of DO. Samples in the quartz bottles were filtered through precombusted glass fiber filters (GF/F, Whatman), with the filtrate being stored at $-20^{\circ} \mathrm{C}$ and used for measuring the fluorescent property and concentration of dissolved organic carbon (DOC). The sampled water was stored at $-80^{\circ} \mathrm{C}$ to determine the phytoplankton cell number and was supplemented with glutaraldehyde with a final concentration of $2.5 \%(\mathrm{v} / \mathrm{v})$. This was subsequently stored at $5^{\circ} \mathrm{C}$ to measure the bacterial cell number. At the beginning of the 1-day experiments, the sampled seawater in the $20-\mathrm{L}$ bottles were filtered by $0.2 \mu \mathrm{m}$ in pore sized membrane filters (Supor, PALL) and afterward stored at $-80^{\circ} \mathrm{C}$ to determine the bacterial compositions using DNA analysis.

\section{Fluorescent Property Measurement}

EEMs were measured by a fluorescence spectrophotometer (F4500, Hitachi) in a quartz cell $(10 \times 10 \mathrm{~mm})$ under following conditions, according to Arai et al. (2018): scan ranges of 250500 and $300-550 \mathrm{~nm}$ for excitation (Ex) and emission (Em), respectively; scan speed of $2400 \mathrm{~nm} \mathrm{~min}{ }^{-1}$; sampling intervals of 5.0 and $2.0 \mathrm{~nm}$ for Ex and Em, respectively; slit width of
$10 \mathrm{~nm}$; and photomultiplier tube voltage of $950 \mathrm{~V}$. Fluorescence intensity was normalized to water Raman scatter peaks of MilliQ water blank (Lawaetz and Stedmon, 2009). EEMs obtained in all experiments $(n=81)$ were analyzed by PARAFAC to separate DOM fluorescence into distinct components (Stedmon and Bro, 2008) using DOMFluor toolbox in MATLAB (R2016a). A splithalf analysis proved the validity of PARAFAC model with the agreement between Ex and Em loadings of randomly divided datasets (Stedmon and Bro, 2008).

\section{Analysis}

The concentration of DO was measured through Winkler potentiometric end-point titration, as per the procedures of sampling, fixation of $\mathrm{DO}$, and calculation of $\mathrm{DO}$ concentrations specified by Kumamoto et al. (2018). A digital burette (VITLAB ${ }^{\circledR}$ continuous E, VITLAB) was used for titrating sodium thiosulfate aqueous solution.

Bacteria cell numbers were counted using epifluorescence microscopy (BX60, OLYMPUS) following the DAPI method (Porter and Feig, 1980; Yokokawa, 2018). Water samples (0.5$2 \mathrm{~mL}$ ) were stained with DAPI and filtered onto black-stained polycarbonate filters $(0.2 \mu \mathrm{m}$, Millipore), with 20 grid fields per sample being enumerated.

The filtered samples were processed using PowerWater DNA Isolation Kit (MO BIO Laboratories) following the instructions of the manufacturer. Subsequently, V3-V4 region of bacterial 16S rRNA gene was amplified using 341f_MIX (5'ACACTCTTTCCCTACACGACGCTCTTCCGATCT-CCTACG GGNGGCWGCAG-3') and 805r_MIX (5'-GTGACTGGAG TTCAGACGTGTGCTCTTCCGATCT-GACTACHVGGGTAT CTAATCC-3') primers. For preparing libraries, the PCR products were subjected to an initial denaturation at $94^{\circ} \mathrm{C}$ for $2 \mathrm{~min}$, followed by 12 cycles of denaturation at $94^{\circ} \mathrm{C}$ for $30 \mathrm{~s}$, annealing at $60^{\circ} \mathrm{C}$ for $30 \mathrm{~s}$, extension at $72^{\circ} \mathrm{C}$ for $30 \mathrm{~s}$, and a final extension at $72^{\circ} \mathrm{C}$ for $5 \mathrm{~min}$. The amplified products were purified using AMPure XP (Beckman Coulter), and afterward, DNA was quantified using Synergy H1 (Bio Tek) and QuantiFluor dsDNA System (Promega). Purified amplicons were pooled in equimolar concentrations and subsequently paired-end sequenced on an Illumina MiSeq instrument (Illumina). The obtained sequence data were then processed using USEARCH 
version 10.0.240 and analyzed with Quantitative Insights software package in Microbial Ecology (QIIME) version 1.9.1 (Caporaso et al., 2010). Sequences were clustered into OTUs using the Greengenes OTU database (97\% similarity). Data are publicly available at the DDBJ Sequence Read Archive (DRASearch: http://trace.ddbj.nig.ac.jp/DRASearch; Accession number: DRA010892).

The concentrations of DOC in the filtrate were measured following a high-temperature catalytic oxidation method (TOC-V, Shimadzu) using potassium hydrogen phthalate as the standard. The system was checked by measuring Hansell Laboratory Deep Seawater Referencel. The DOC concentration of the reference (Batch-16) was $42.6 \pm 0.9 \mu \mathrm{MC}$ in this study.

Phytoplankton cell numbers were determined through a flow-cytometry (FACS Calibur; 4-color type; Becton-Dickinson) equipped with an argon ion laser (488 $\mathrm{nm})$ and a red semi-conductor laser $(635 \mathrm{~nm})$. Emitted fluorescence was monitored at FL2 (585 $\pm 21 \mathrm{~nm}$ : orange), FL3 (670 nm: long-pass red), and at a forward-light scatter and a side-light scatter. Fluoresbrite microspheres (6 and $10 \mu \mathrm{m}$; Polysciences) were used to adjust the instrumental conditions. Samples were analyzed for 40-900 s at an average flow rate of $64.9 \mu \mathrm{L} \mathrm{min}^{-1}$.

The concentrations of nitrate, nitrite, and phosphate in the samples at the beginning of the experiments at Shimoda and Misaki were determined by colorimetric techniques using an autoanalyzer (AACSII, BRAN + LUEBBE).

\section{Statistical Analysis}

Effect of addition nutrition to DOC concentration at the beginning of the 1-day experiment was tested with two-way ANOVA using "location of seawater sampling" and "treatment of nutrients" as the factors. Furthermore, a pair-wise multiple comparison with post hoc Tukey's test was performed. Changes in the fluorescence intensities under dark condition at the time points from the beginning to the end of the experiments were analyzed using a LMM (R package: lmerTest, function: lmer; Kuznetsova et al., 2017) with "time point" as a fixed factor. The seven kinds of "seawater samples" were treated as a random factor. Homogeneity of variance and normality were evaluated using Levene Test and QQ plot, displaying that the fluorescent intensities conformed to these assumptions. Moreover, a post hoc test was used with the function of lsmeans (R package: lsmeans, Lenth, 2016). To assess the effect of photobleaching, fluorescence intensities of the sample, with and without sunlight exposure, should be compared. Therefore, LMM was used to do this comparison using "seawater samples" as a random factor. The response of fluorescence intensity for DO consumption was estimated based on the slope of regression line in the LMM using "DO concentration" as a fixed factor and "seawater samples" as a random factor. In this study, all statistical analyses were performed using the R statistical software, version 3.5.1 (R Core Team, 2018).

\footnotetext{
${ }^{1}$ https://hansell-lab.rsmas.miami.edu/consensus-reference-material/index.html
}

\section{RESULTS}

\section{Sample Conditions}

Table 1 shows the cell numbers of bacteria and phytoplankton, DOC concentrations, nutrient concentrations of nitrite + nitrate and phosphorite, and PAR during the day in each experiment. The lowest phytoplankton numbers and DOC concentrations were noted in the subtropical Pacific, indicating less biological activity. The nutrient-added samples were incubated for 3 days and the nutrient enrichment was observed to simulate the organic matter production. The DOC concentrations in the nutrientadded samples were significantly higher than that in the natural samples collected from the subtropical Pacific and Shimoda (TukeyHSD, $p<0.05$ ) (Supplementary Table S1).

\section{FDOM Components Determined by PARAFAC}

Three fluorescent components were identified from the EEMs for all experiments through PARAFAC analysis (Figure 1). Component $1(\mathrm{C} 1)$ and 2 (C2) were characterized as humiclike FDOM (Coble, 1996). C1 showed two excitation maxima (255 and $370 \mathrm{~nm}$ ) and an emission maximum at $484 \mathrm{~nm}$, similar to humic-like A (Coble, 1996; Stedmon et al., 2003). Although humic-like A was traditionally categorized as terrestrial humic substance (Coble, 1996), it was reported to be observed in the pelagic ocean (Kowalczuk et al., 2013; Tanaka et al., 2014; Catalá et al., 2015; Yamashita et al., 2017). The incubations of coastal bacterial communities showed that humic-like A was produced as the by-product of bacterial metabolism during organic matter decomposition (Shimotori et al., 2009; Romera-Castillo et al., 2011; Arai et al., 2018). C2 was characterized as marine humic-like FDOM (Coble, 1996), which was blue-shifted from C1 and exhibited two Ex maxima ( $<250$ and $325 \mathrm{~nm}$ ) and an Em maximum (406 nm). $\mathrm{C} 2$ are known as the microbially produced FDOM in the ocean, corresponding to humic-like M (Coble, 1996). The maxima of Ex and Em for components 3 (C3) (280/316) were comparable to those of tyrosine-like peak, as previously reported (Yamashita and Tanoue, 2003; Stedmon and Markager, 2005; Murphy et al., 2008).

\section{Diurnal Changes in the Fluorescence Intensities of the Three Components}

The fluorescence intensity of each component significantly varied among the seawater sample collection sites. The lowest values were found in the subtropical Pacific, with the fluorescence intensities of $\mathrm{C} 1$ being $0.36 \pm 0.01 \times 10^{-2}$ and $0.41 \pm 0.004 \times 10^{-2}$ R.U. (mean values of the three bottles \pm SEs) for the natural and nutrient-added samples at the beginning of the 1-day experiments (sample B), respectively. In the coastal and bay seawaters at Shimoda (August and April) and Misaki, respectively, the fluorescence intensities of the natural samples were found to be $2.08 \pm 0.05 \times 10^{-2}, 2.72 \pm 0.03 \times 10^{-2}$, and $4.57 \pm 0.02 \times 10^{-2}$ R.U., respectively, which were an order of magnitude higher than those observed in the subtropical seawater. The highest fluorescence intensity of the natural sample 
A

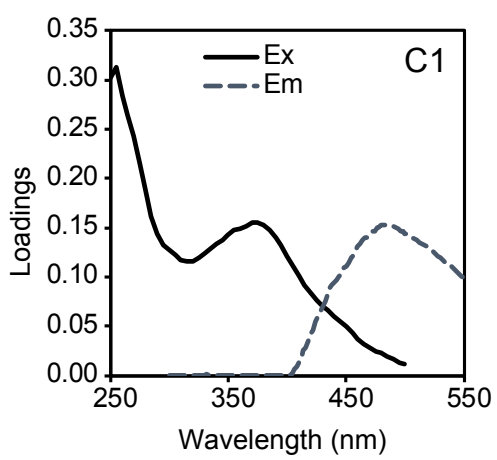

B

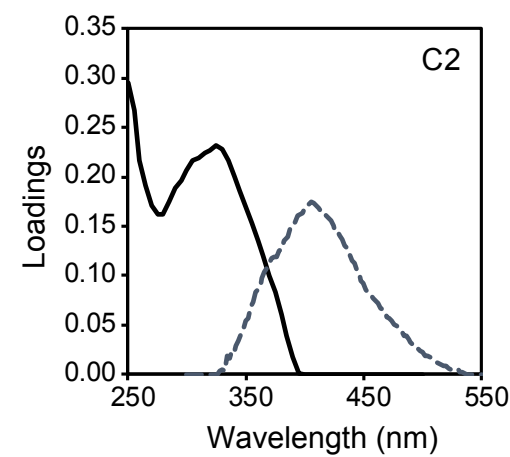

C

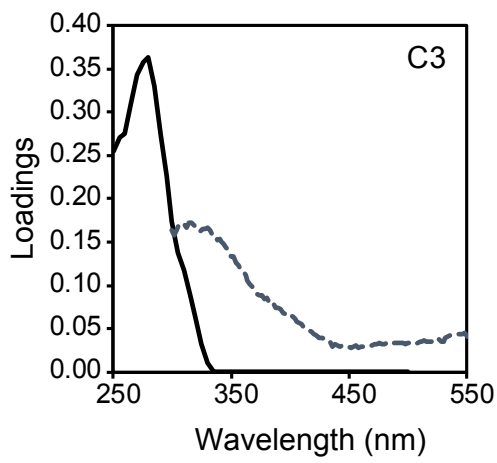

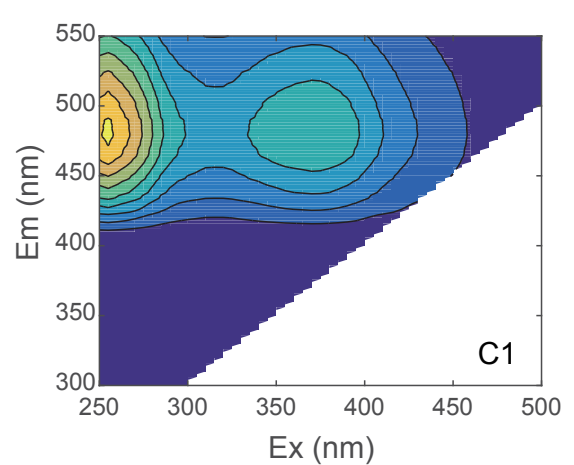
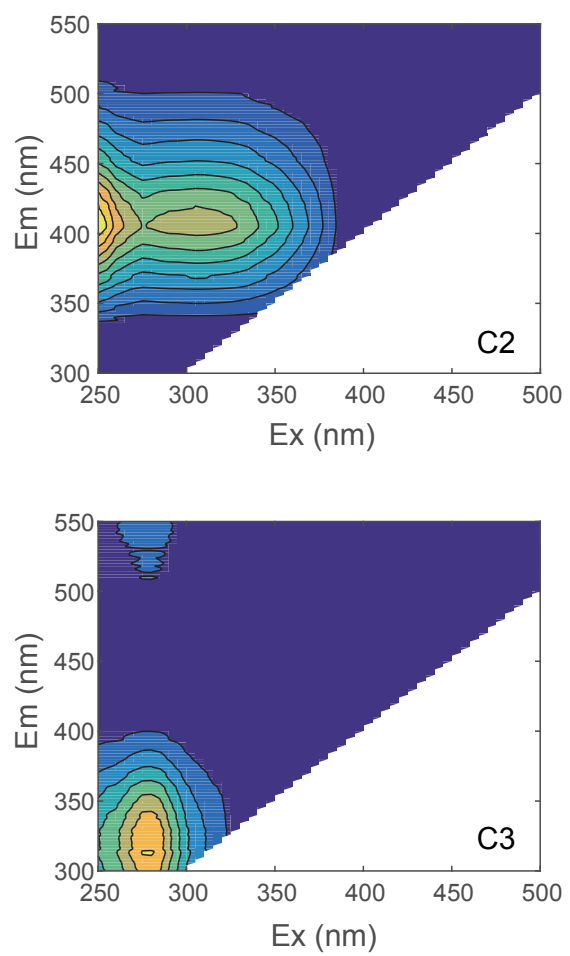

FIGURE 1 | PARAFAC model results showing the fluorescence signature of the three components of C1 (A), C2 (B), and C3 (C). Left figures show the line plots of excitation (Ex: solid lines) and emission (Em: dash lines) spectra and right figures show the counter plots of EEMs.

in Misaki reflected the inflow of terrestrial humic substances due to the precipitation of the previous day.

The fluorescence intensities of $\mathrm{C} 1$ at the beginning, morning, and day under dark condition, for samples B, M, and DD, respectively, consistently increased throughout the experiments (Figure 2). The intensities in samples $\mathrm{M}$ were 102.6-105.6\% (mean value of seven experiments \pm SE: $104.3 \pm 1.3 \%$ ) higher for all experiments compared to those of samples B. During the day, the intensity additionally increased under the dark condition and the values of samples DD ranged from $0.44 \pm 0.02 \times 10^{-2}$ to $4.75 \pm 0.00 \times 10^{-2}$ R.U., corresponding to $103.9-128.1 \%$ (mean value \pm SE: $113.9 \pm 3.1 \%$ ) of the intensity in samples B. Regarding using "seawater samples" as a random factor, the fluorescence intensity of C1 significantly increased along the time point (LMM: $F_{2,50}=35.93, p<0.001$, least-squares means: $p<0.01$; Table 2).

The fluorescence intensities of $\mathrm{C} 2$ in the subtropical Pacific were $0.30 \pm 0.01 \times 10^{-2}$ and $0.25 \pm 0.01 \times 10^{-2}$ R.U. for the natural and nutrient-added samples, respectively, at the beginning (samples B), which were the lowest values among all sites and C1 (Figure 3). The fluorescence intensities in Shimoda in August and April and Misaki were $2.04 \pm 0.11 \times 10^{-2}$, $1.86 \pm 0.00 \times 10^{-2}$, and $4.09 \pm 0.01 \times 10^{-2}$ R.U., respectively. The fluorescence intensities of $\mathrm{C} 2$ changed slightly between samples B and $M$, except for the nutrient-added samples from the subtropical Pacific, which increased during the night (Figure 3B). Afterward, the intensities of C2 in samples DD were observed to be higher than those of samples $\mathrm{M}$. The fluorescence intensity of 

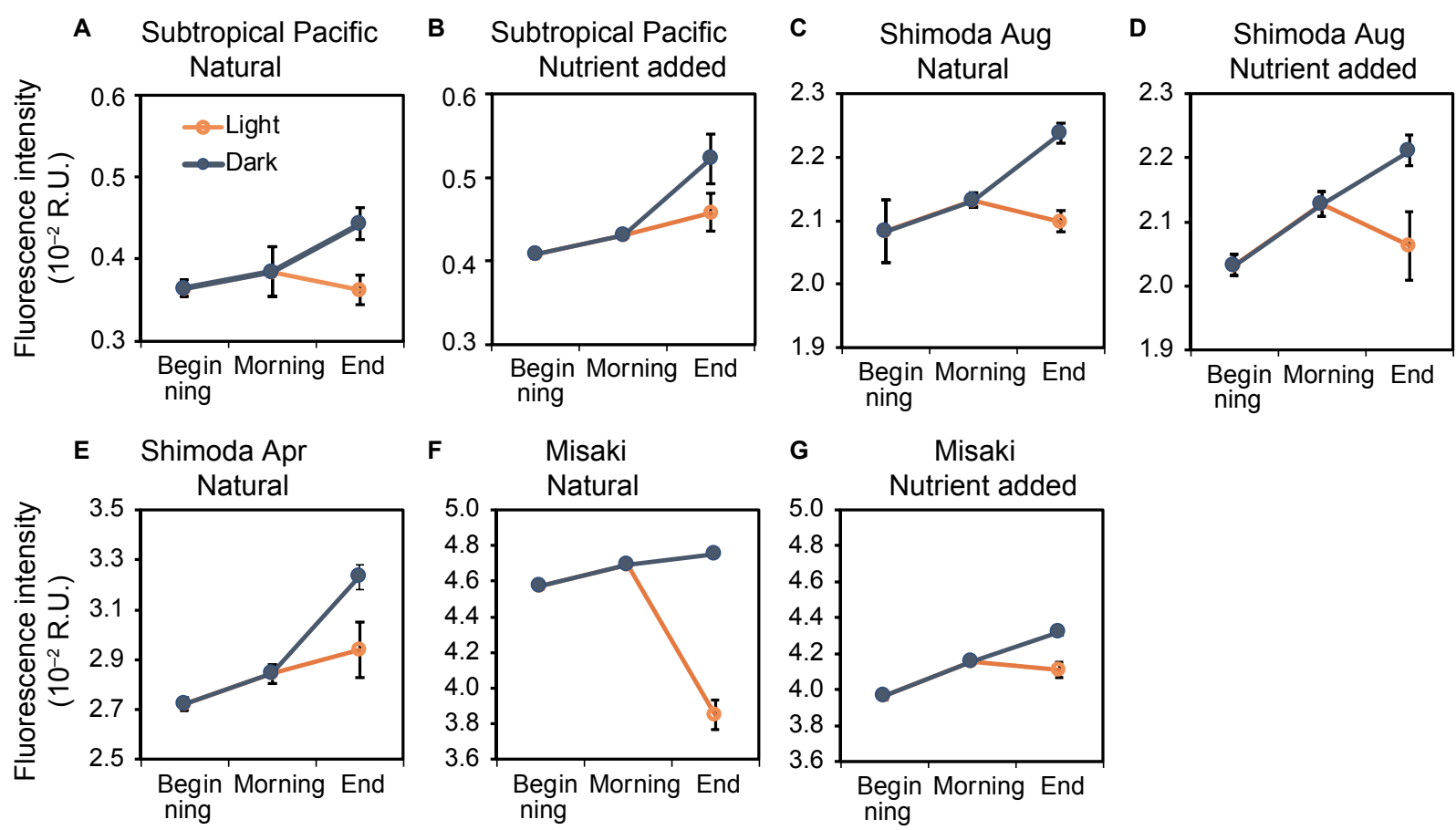

FIGURE 2 | Changes in the fluorescence intensities of $\mathrm{C} 1$ at the beginning, morning, and end of the experiments in the natural and nutrient-added seawater collected from the subtropical Pacific (A,B), Shimoda in August $\mathbf{( C , D )}$ and April $\mathbf{( E )}$, Misaki $\mathbf{( F , G ) . ~ T h e ~ b l u e ~ a n d ~ o r a n g e ~ l i n e s ~ r e p r e s e n t ~ t h e ~ c h a n g e s ~ u n d e r ~ t h e ~ d a r k ~}$ and light conditions, respectively. The error bars represent the standard error $(n=3)$.

TABLE 2 | LLM analysis for C1.

\begin{tabular}{llclll}
\hline Time points & Estimates & SE & $\boldsymbol{d f}$ & $\boldsymbol{t}$ ratio & $\boldsymbol{p}$-value \\
\hline Morning vs DD & 0.0014 & 0.00026 & 50 & 5.35 & $<0.001$ \\
Beginning vs DD & 0.00222 & 0.00027 & 50 & 8.36 & $<0.001$ \\
Beginning vs morning & 0.00083 & 0.00027 & 50 & 3.1 & $<0.01$ \\
\hline
\end{tabular}

C2 significantly increased from the beginning to the end of the experiments (LMM with "seawater samples" used as a random factor: $F_{2,50}=3.89, p<0.05$, least-squares means: $p<0.01$; Table 3).

The fluorescence intensities of $\mathrm{C} 3$ in samples $\mathrm{B}$ in all incubation experiments ranged from $0.98 \pm 0.02 \times 10^{-2}$ to $3.44 \pm 0.07 \times 10^{-2}$ R.U. (Figure 4). LMM analysis showed no significant changes in the fluorescence intensities of C3 among samples $\mathrm{B}, \mathrm{M}$, and $\mathrm{DD}$ in all experiments (LMM: $F_{2,50}=2.53$, $p<0.1)$.

The exposure to sunlight evidently decreased the fluorescence intensities of all components. The fluorescence intensities of $\mathrm{C} 1$ in sample DL ranged between $0.36 \pm 0.02 \times 10^{-2}$ and $4.11 \pm 0.04 \times 10^{-2}$ R.U. (Figure 2), significantly lower than those in samples DD (LMM: $F_{1,32}=32.00, p<0.001$ ) and comparable to those of samples B. Additionally, the fluorescence intensities of C2 and C3 also significantly declined in sample DL due to exposure to sunlight (LMM for C2: $F_{1,32}=39.70, p<0.001 ; \mathrm{LMM}$ for $\left.\mathrm{C} 3: F_{1,32}=7.84, p<0.01\right)$ (Figures 4, 5).

\section{Turnover Rate of $\mathbf{C 1}$ by Production and Photobleaching}

We estimated the turnover rates of $\mathrm{C} 1$ because the fluorescence intensity of $\mathrm{C} 1$ showed a clear diurnal variation and its intensities at the beginning and end of the 1-day experiments (samples $\mathrm{B}$ and DL) were almost same (Figure 2). The daily increase rate in the fluorescence intensity of $\mathrm{C} 1$ in each experiment was calculated using the difference between the intensities of samples $\mathrm{B}$ and DD (Table 4). The increase rates of C1 ranged from 7.9 to $61 \times 10^{-4}$ R.U. day ${ }^{-1}$; the lowest observed in the subtropical seawater and the highest in Shimoda in April. The turnover rate of $\mathrm{C} 1$ was estimated as the ratio of the increasing rate and fluorescence intensity of sample B obtained in each experiment. The turnover rates of $\mathrm{C} 1$ calculated by the increase (TRi) in all experiments ranged from 0.04 to $0.27 \mathrm{day}^{-1}$, with an average of $0.14 \pm 0.031 \mathrm{day}^{-1}$ (Table 4). The lowest turnover rate was estimated in the natural seawater in Misaki because of the highest intensity at the beginning of the experiment probably due to an inflow of the terrestrial FDOM (Figure 2).

Fluorescent DOM was photobleached during the day due to sunlight exposure concomitant with the production. As the decrease in the fluorescence intensity of $\mathrm{C} 1$ in sample DL was considered as a net decrease, the gross decrease was estimated as the sum of its decrease under sunlight exposure and its increase under dark condition during the day. The gross daily decrease rates of $\mathrm{C} 1$ by photobleaching ranged from 5.9 to $89 \times 10^{-4}$ R.U. $\mathrm{day}^{-1}$ in all experiments (Table 4). The highest gross decrease rate was observed in the natural samples in Misaki, because 

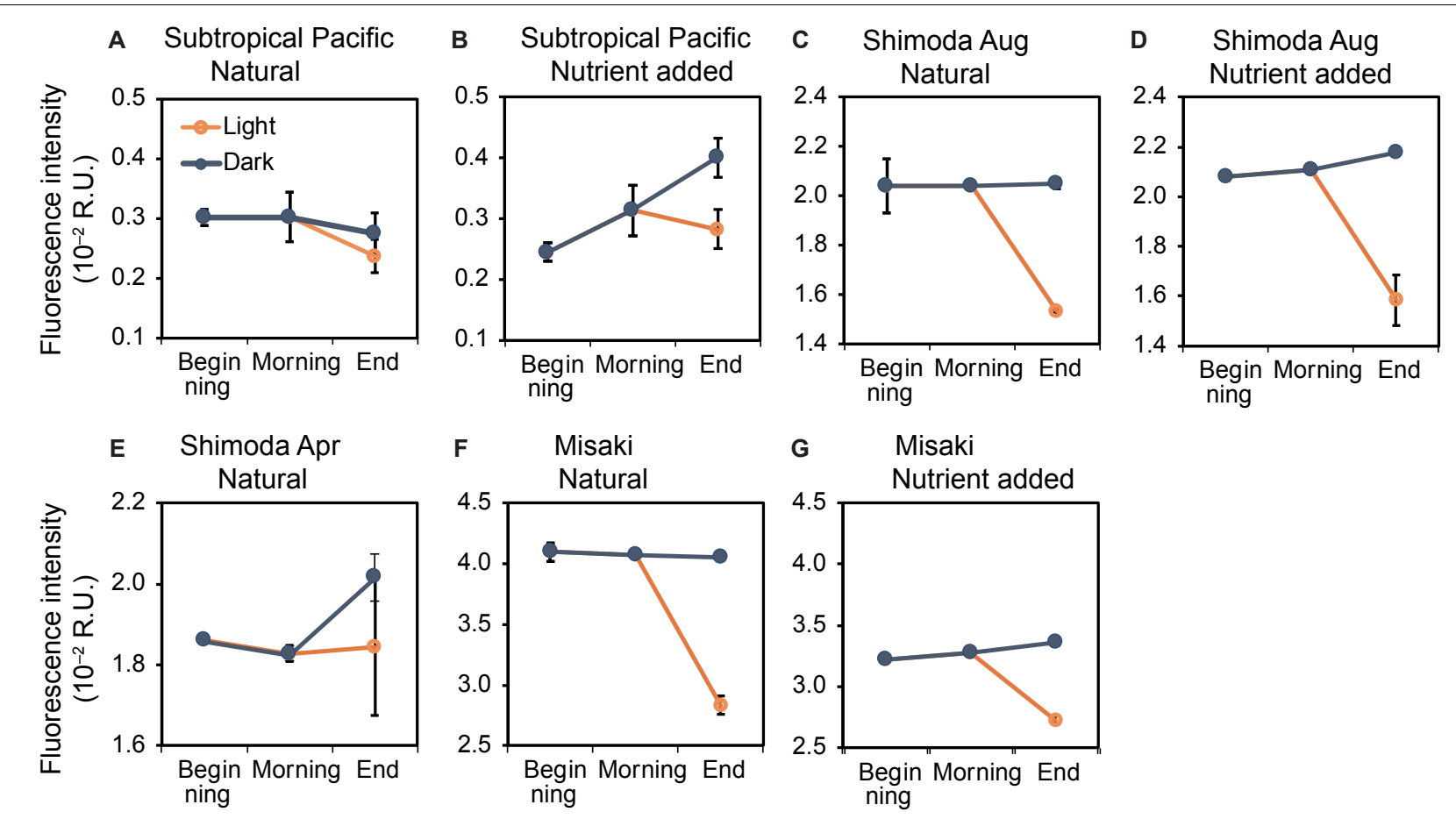

FIGURE 3 | Changes in the fluorescence intensities of C2 at the beginning, morning, and end of the experiments in the natural and nutrient-added seawater collected from the subtropical Pacific (A,B), Shimoda in August (C,D) and April (E), Misaki (F,G). The blue and orange lines represent the changes under the dark and light conditions, respectively. The error bars represent the standard error $(n=3)$.

TABLE 3 | LLM analysis for C2.

\begin{tabular}{lccccc}
\hline Time points & Estimates & SE & $\boldsymbol{d f}$ & $\boldsymbol{t}$ ratio & $\boldsymbol{p}$-value \\
\hline Morning vs DD & 0.0006 & 0.00026 & 50 & 2.25 & 0.0733 \\
Beginning vs DD & 0.00069 & 0.00027 & 50 & 2.55 & $<0.05$ \\
Beginning vs morning & 0.00009 & 0.00027 & 50 & 0.34 & 0.939 \\
\hline
\end{tabular}

the inflowed terrestrial humic substances are high photosensitive (Obernosterer and Benner, 2004). On the other hand, the gross decrease rate of the nutrient-added samples in Misaki was lower than that of the natural samples (Table 4). The reason might be that the photo-sensitive fraction including the terrestrial humic substances had been photo-bleached during the incubation under sunlight exposure prior to the 1-day experiment. The mean value of its turnover rate by gross decrease (TRd) was $0.12 \pm 0.021 \mathrm{day}^{-1}$, ranging from 0.05 to $0.20 \mathrm{day}^{-1}$, similar to the range of Tri.

\section{Diurnal Variations in DO Concentrations}

The initial values of DO concentrations ranged from 201.5 to $227.8 \mu \mathrm{M}$. During the night, the DO concentrations decreased in all coastal seawater except remaining unchanged in the subtropical seawater (Supplementary Figure S1). All of them showed consistent decreases during the day under dark conditions, representing oxygen consumption by bacterial respiration. Regarding using "seawater samples" as a random factor, the DO concentrations significantly decreased in the samples collected from $\mathrm{B}, \mathrm{M}$, and $\mathrm{DD}$, along the time points under dark conditions (LMM: $F_{2,52}=63.40, p<0.001$, leastsquares means: $p<0.001$; Supplementary Table S2). The DO concentrations in all DL samples were significantly higher than those in all DD samples due to photosynthesis (LMM: $F_{1,33}=10.97, p=0.002$ ). The changes in DO concentration under sunlight exposure would reflect both production and consumption of oxygen. Quantitative evaluations were limited to use the changes in DO under dark conditions reflecting microbial respiration.

The fluorescence intensity of $\mathrm{C} 1$ was closely related to the DO concentration (LMM, random factor: "seawater sample", $p<0.01$ ) (Supplementary Figure S2). The slope value was $-1.08( \pm 0.22) \times 10^{-4}$ (fluorescent intensity/DO concentration; R.U./ $\mu \mathrm{M})$. Other two components, $\mathrm{C} 2$ and $\mathrm{C} 3$, were not found to be closely related to DO concentration in this study $(p=0.23$ and 0.30 , respectively).

\section{Bacterial Composition}

The composition of bacteria taxa varied among the seawater sample. Heterotrophic bacteria were predominant in four seawater samples, while cyanobacteria were predominant in two samples (Supplementary Figure S3). The order Chrolophyta, family Mamiellaceae accounted for 45 and 52\% of the total bacterial abundance in the natural sample in Shimoda in August and the nutrients-added sample in Misaki bay, respectively. In addition, the order Synechococcales, family Synechococcaceae was one of the major bacteria groups in the subtropical Pacific. 

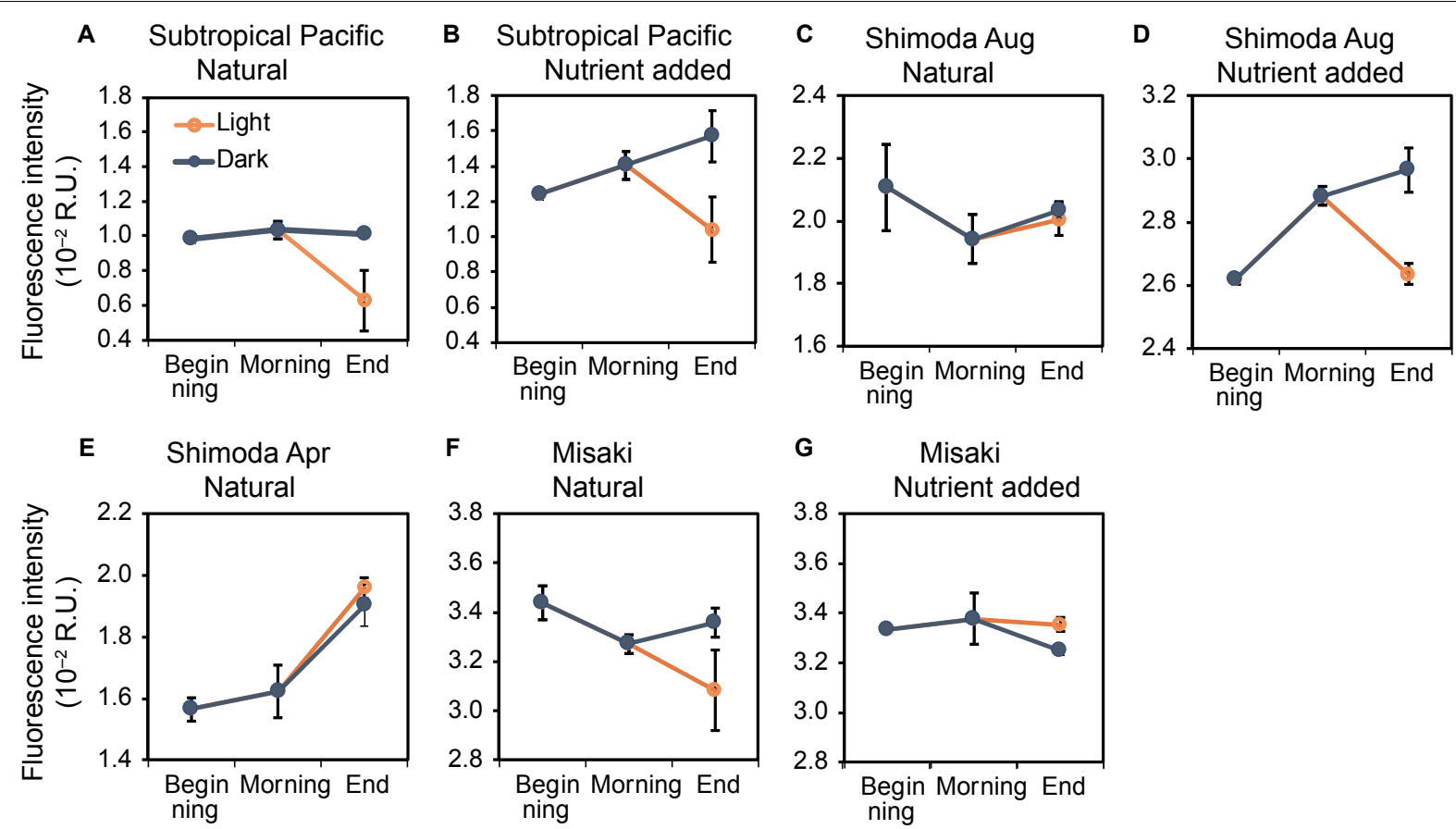

FIGURE 4 | Changes in the fluorescence intensities of C3 at the beginning, morning, and end of the experiments in the natural and nutrient-added seawater collected from the subtropical Pacific (A,B), Shimoda in August (C,D) and April (E), Misaki (F,G). The blue and orange lines represent the changes under the dark and light conditions, respectively. The error bars represent the standard error $(n=3)$.

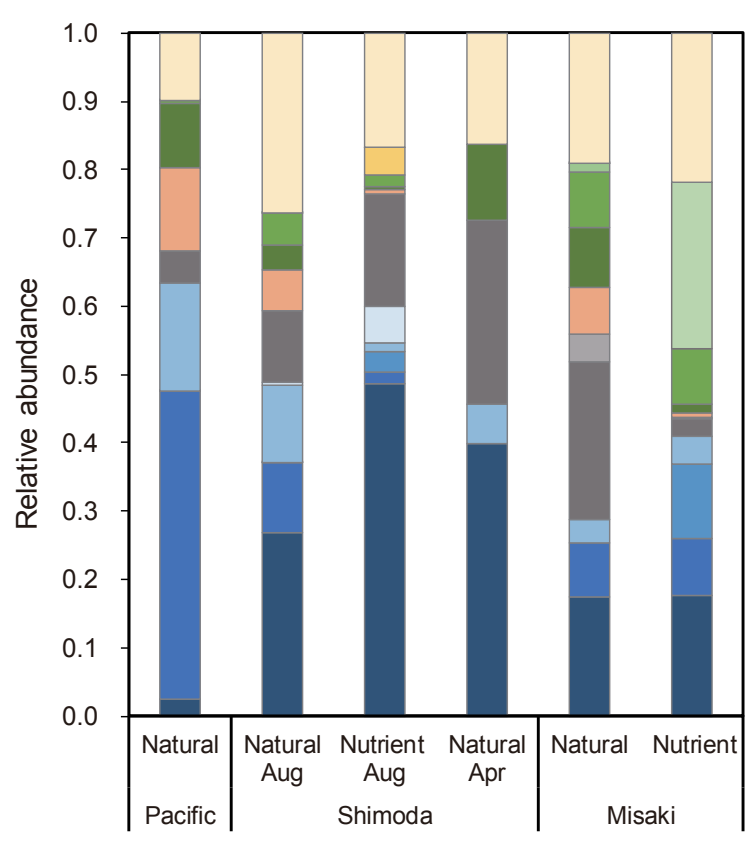

- Rhodobacterales

- Rickettsiales

- Kiloniellales

$\square$ Alphaproteobacteria

(Unknown)

$\square$ Rhizobiales

- Flavobacteriales

$\square$ Sphingobacteriales

$\square$ Acidimicrobiales

- Oceanospirillales

- Alteromonadales

$\square$ Rhodocyclales

$\square$ Gammaproteobacteria

(Unknown)

$\square$ Planctomycetes

(Unknown)

$\square$ Others

FIGURE 5 | Relative abundance of heterotrophic bacterial orders at the beginning of each experiment, showing the taxonomic groups with abundances greater than $1 \%$. "Natural" and "Nutrient" mean the natural seawater and the nutrient added seawater, respectively.

Heterotrophic bacteria groups in the subtropical surface seawater differed from those of the coastal areas (Figure 5). Rickettsiales accounted for $45 \%$ of the total heterotrophic bacterial abundance in the subtropical Pacific. Among the order Rickettsiales, family Pelagibacteraceae was found as a major group (85-94\% of the Rickettsiales), which is known as "SAR11 
TABLE 4 | Rates of change of the fluorescence intensities of C1 and its turnover rates by the increase and decrease.

\begin{tabular}{|c|c|c|c|c|c|c|}
\hline & & Nutrient $^{a}$ & $\begin{array}{c}\text { Increase rate } \\
{\left[\times 10^{-4} \text { R.U. day }{ }^{-1}\right]}\end{array}$ & $\begin{array}{l}\text { Turnover rate } \\
\left(\mathrm{TRi}^{b}\right)\left[\text { day }^{-1}\right]\end{array}$ & $\begin{array}{l}\text { Gross decrease rate } \\
{\left[\times 10^{-4} \text { R.U. day }{ }^{-1}\right]}\end{array}$ & $\begin{array}{l}\text { Turnover rate } \\
\left(\mathrm{TRd}^{c}\right)\left[\mathrm{day}^{-1}\right]\end{array}$ \\
\hline \multirow[t]{2}{*}{ Subtropical Pacific Ocean } & 2016 Jul & No add & 7.9 & 0.22 & 7.2 & 0.20 \\
\hline & & Add & 11 & 0.27 & 5.9 & 0.14 \\
\hline \multirow[t]{3}{*}{ Shimoda } & 2016 Aug & No add & 16 & 0.074 & 13 & 0.063 \\
\hline & & Add & 18 & 0.088 & 14 & 0.069 \\
\hline & 2018 Apr & No add & 61 & 0.22 & 31 & 0.11 \\
\hline \multirow[t]{2}{*}{ Misaki } & 2017 Sep & No add & 20 & 0.043 & 89 & 0.19 \\
\hline & & Add & 36 & 0.091 & 20 & 0.051 \\
\hline
\end{tabular}

a "No add" and "Add" of nutrient mean the natural seawater and the nutrient added seawater, respectively.

${ }^{b}$ TRi (turnover rate calculated by the increase rate) was estimated as the ratio of the increase rate and the fluorescence intensity of sample $B$.

${ }^{c}$ TRd (turnover rate calculated by the gross decrease rate) was estimated as the ratio of the gross decrease rate and the fluorescence intensity of sample $B$.

bacterial clade," being the most abundant heterotrophic bacteria in the oceans worldwide (Morris et al., 2002). In Shimoda, Rhodobacterales, which belongs to Alphaproteobacteria class of Proteobacteria phylum, accounted for the highest proportion of 26-49\%. Flavobacteria that belong to Flavobacteriia class in Bacteroidetes phylum accounted for 27 and 23\% of bacterial taxa in the surface seawater in Shimoda in April and Misaki, respectively. Both bacterial groups of Rhodobacterales and Flavobacteria have been found to be the dominant groups associated phytoplankton bloom (Buchan et al., 2014).

\section{DISCUSSION}

\section{Production of Humic-Like FDOM in Surface Seawater}

Photobleaching due to sunlight exposure has been considered as one of the most essential processes in humic-like FDOM dynamics taking place in the surface layer because the fluorescence intensity of humic-like FDOM is always low (Omori et al., 2010; Jørgensen et al., 2011; Timko et al., 2015). However, for the intensity of humic-like FDOM to be steady in the surface layer, its photobleaching rate should equilibrate with its production rate. The fluorescence intensity of humic-like FDOM in the surface water from the North to South Pacific Ocean revealed higher intensity in the area with higher chlorophyll a concentration (Yamashita et al., 2017). This implied that humiclike FDOM production by biological activity originating from phytoplankton is one of the factors that impact its geographical distribution. Although its production in the surface layer is necessary to clarify the dynamics of FDOM, little research has been done on this (Nieto-Cid et al., 2006; Lønborg et al., 2015).

In this study, the fluorescence intensities of two components of humic-like FDOM, C1 and C2, indicated significant increase in samples B to DD (Figures 2, 3 and Tables 2, 3). Especially for $\mathrm{C} 1$, the fluorescence intensities in samples $\mathrm{B}, \mathrm{M}$, and DD were correlated with those of DO concentrations (Supplementary Figure S2). This experimental analysis strongly suggested that humic-like FDOM are produced as the by-products of microbial respiration processes in the surface seawater (Nieto-Cid et al., 2006; Lønborg et al., 2015) as well as in mid-deep ocean
(Hayase and Shinozuka, 1995; Yamashita and Tanoue, 2008; Omori et al., 2010; Jørgensen et al., 2011; Catalá et al., 2015).

The microbial community in our experiments includes bacteria, archaea, and phytoplankton excluding large zooplankton. Among them, marine bacteria are considered to be one of the major producers of FDOM. Bacterial respiration in coastal surface seawater has been shown to account for over $60 \%$ of community respiration (Kirchman et al., 2009; GonzálezBenítez et al., 2019), suggesting that the increase in C1 associated with oxygen consumption is mainly due to bacteria. Some experimental studies have evidenced that humic-like FDOM are produced from marine bacteria in the surface seawater under dark condition (Yamashita and Tanoue, 2003), artificial seawater added with natural bacteria community (Kramer and Herndl, 2004; Shimotori et al., 2009; Arai et al., 2018), and cultured experiments (Shimotori et al., 2012; Goto et al., 2017). Cyanobacteria were present as the dominant groups in the two samples of our experiments (Supplementary Figure S3). Since cyanobacteria directly produce humic-like FDOM (Zhao et al., 2017), it is considered that not only heterotrophic bacteria, but also photosynthetic bacteria contribute to FDOM production in the surface seawater. Phytoplankton can be considered as another FDOM producer. Although there is little knowledge on the FDOM production by phytoplankton, experimental study using 11 algal cultures showed that phytoplankton did not contribute to the FDOM pool (Rochelle-Newall and Fisher, 2002). Meanwhile, other studies showed the exudation of marine humic-like FDOM from four species of phytoplankton including diatom, dinoflagellate, and prasinophyte (Romera-Castillo et al., 2010, 2011). In our experiments, part of the increase in C2 (marine humic-like FDOM) that was not correlated with the oxygen consumption may be due to exudation from phytoplankton.

The ratio of the fluorescence intensities of $\mathrm{C} 1$ to $\mathrm{C} 2$ consistently increased from samples $B$ to DD, except for the nutrient-added seawater of the subtropical Pacific (Supplementary Figure S4). The increase in C1/C2 indicated that the net production of $\mathrm{C} 1$ from microbial activity was higher than that of $\mathrm{C} 2$. The distribution of humic-like FDOM in the dark ocean also suggested the higher production per oxygen consumption of humic-like A (C1 in this study) than humic-like M (C2) (Catalá et al., 2015). According to Shimotori et al. (2012), 
the fluorescent property of humic-like FDOM derived from coastal bacteria varied depending on the bacteria taxonomic groups. They demonstrated that bacteria species belonging to Alteromonadales and Oceanospirillales, each accounting for approximately $10 \%$ in our experiments (Figure 5), produced humic-like A and M. Rhodobacterales, which was one of the main bacteria groups found in the samples collected from Shimoda and Misaki (Figure 5), only produced humic-like M. Although humic components produced by major bacteria groups detected in this study, including Flavobacteriales and Rickettsiales, have not been reported (Shimotori et al., 2012), an increase in C1/C2 implied that some bacteria groups that produced more humic-like A than $\mathrm{M}$ dominated during these experiments. Conversely, ratio $\mathrm{C} 1 / \mathrm{C} 2$ in the nutrient-added seawater of the subtropical Pacific decreased from samples $B$ to DD due to higher increase in the intensity of C2 than that of C1 (Figures 2, 3 and Supplementary Figure S4). Although bacterial composition was not determined in the nutrient-added subtropical seawater, it was considered that the composition might change to the species which actively produce humic-like $M$.

Difference in the bacterial degradability $\mathrm{C} 1$ and $\mathrm{C} 2$ is considered as another factor for the lower increase in the intensity of C2 than that of C1. Romera-Castillo et al. (2011) evaluated the FDOM behaviors in bacterial incubation experiments using marine phytoplankton exudates as the substrates. They demonstrated that humic-like $\mathrm{M}$ was consumed by bacteria and red-shifted humic-like FDOM (humic-like A) was stable to bacterial degradation. The lower increase in the intensity of C2 in our experiments could be due to its bacterial degradation just after production.

\section{Diurnal Variations of Humic-Like FDOM and Their Photobleaching}

In this study, it was experimentally demonstrated that humic-like FDOM varied diurnally in surface seawater from the bay to the pelagic ocean (Figures 2, 3). The fluorescence intensity of $\mathrm{C} 1$ significantly increased due to microbial production during the night and decreased due to photobleaching by sunlight exposure during the day (Figure 2). C2 also slightly increased during the night and significantly decreased during the day (Figure 3). In addition, both humic-like components were continuously produced via microbial metabolism during the day, as shown for samples DD (Tables 2, 3). These diurnal variations suggested that the production of humic-like FDOM and its photobleaching were happening simultaneously during the day. The mean TRd and TRi of C1 were estimated to be 0.14 and 0.11 day $^{-1}$, respectively (Table 4). These similar turnover rates also supported the near equilibrium in the production and photobleaching of humic-like FDOM, with its level being low in the surface water.

The ratio of the fluorescence intensities of $\mathrm{C} 1$ to $\mathrm{C} 2$ of samples DL was significantly higher than those of samples DD (Supplementary Figure S5; LMM for C1/C2: $F_{1,32}=7.97$, $p<0.01)$. The higher ratio of $\mathrm{C} 1 / \mathrm{C} 2$ of samples $\mathrm{DL}$ indicated that the decrease in the intensity of $\mathrm{C} 2$ by photobleaching was higher than that of $\mathrm{C} 1$. C2 (humic-like $\mathrm{M}$ ) was indicated to be more sensitive to photobleaching than C1 (humic-like A), which was consistent with the results obtained from the experiments that used humic-like FDOM derived from bacteria. Arai et al. (2018) compared the photodegradability of humic-like FDOM produced by bacteria in exposure experiments using a solar simulator. The ratio of intensity after 24-h exposure to the initial intensity was 10 and $48 \%$ for humic-like $\mathrm{M}$ and $\mathrm{A}$, respectively. In contrast, results obtained from the experiments with humic-like FDOM from the natural seawater showed higher photosensitivity of humic-like A than M. Helms et al. (2013) conducted a photo exposure experiment with seawater collected from a depth of $674 \mathrm{~m}$ in the North Pacific Ocean and demonstrated that the fluorescence intensity of humic-like A decreased to $18 \%$ of the initial intensity, which was $25 \%$ for humic-like M. Light exposure experiments with deep seawater in the Sargasso Sea also indicated that the intensity of humic-like A significantly decreased during 24-h exposure, whereas change in the intensity of humic-like $\mathrm{M}$ indicated less photosensitivity (Timko et al., 2015). Thus, the photosensitivities of humic-like $A$ and $M$ in the deep ocean were inconsistent with those in the surface seawater and bacterial culture. Humic-like $A$ and $M$ in the deep ocean were considered to persist for long-term, estimated to be 400600 years (Catalá et al., 2015), while those in the surface seawater and bacterial culture should be fresher than those in the deep ocean. Differences in the freshness of humic-like FDOM might affect the photosensitivities of humic-like $\mathrm{A}$ and $\mathrm{M}$, even with same fluorescent properties in the deep and surface seawater.

\section{Diurnal Variation of Tyrosine-like FDOM}

The behavior of C3 reflects that of polypeptide and protein, including tyrosine, which was comparable as a labile DOM (Yamashita and Tanoue, 2003; Nieto-Cid et al., 2006; Lønborg et al., 2010, 2015). Changes in the fluorescence intensities of C3 from the beginning to the end of the experiments under dark conditions were found to be vary among the seven experiments (Figure 4). A slight change in C3 indicated the active occurrence of both microbial production and decomposition. Conversely, significant decreases in the intensity of $\mathrm{C} 3$ were found under sunlight exposure during the day (Figure 4). Although C3 production through phytoplankton photosynthesis has been expected to increase the fluorescence intensity of C3 during the day (Nieto-Cid et al., 2006), the rate of photobleaching due to sunlight exposure was probably higher than that of production. Culture experiments revealed that tyrosine-like FDOM was reduced by photoirradiation without bacterial activity (Mostofa et al., 2013; Arai et al., 2018). Therefore, the distribution of tyrosine-like FDOM in the surface layer was likely to vary by biological activity as well as photobleaching due to sunlight exposure.

\section{Importance of Photobleached Humic-Like FDOM in Biogeochemical Cycle}

Humic-like FDOM has been attracting attention as an indicator of the behavior of biological RDOM due to its dynamics. The global distribution of humic-like FDOM shows that humiclike $\mathrm{A}$ and $\mathrm{M}$ are suitable markers of RDOM with turnover 
time range of 400-600 years, indicating that the in situ microbial production of humic-like FDOM in dark ocean is a sink of reduced carbon in the timescale of hundreds of years (Catalá et al., 2015). Conversely, our experimental analysis estimated the turnover time of $\mathrm{C} 1$ in the surface seawater to be approximately 10 days, which was in the same range as that of biological labile DOM, such as carbohydrate and protein, with turnover times of 5-10 days (Benner and Amon, 2015). In this study, it was clearly shown that humiclike FDOM behaved as a highly dynamic fraction of marine DOM due to microbial production and photobleaching in the surface layer. However, the short turnover of humic-like FDOM implied a short life of its fluorophore, without reflecting the behaviors of organic carbon. Photobleached FDOM has been reported to undergo different processes after sunlight exposure: mineralization (Mopper et al., 1991), formation of low-molecular DOM, including oxygenated volatile organic compounds (Kieber et al., 1990; Mopper et al., 1991; Zhou and Mopper, 1997), transformation to biological labile DOM to be consumed by bacteria (Moran et al., 2000; Yang et al., 2020), and remaining as RDOM without the fluorescent property (Kramer and Herndl, 2004). Although no method exists for measuring FDOM lost fluorophore, it has been considered that it may remain as organic substances as post-FDOM (Omori et al., 2015).

The linear relationships between the fluorescence intensities of C1 and DO concentrations observed in the 1-day experiments (Supplementary Figure S2) facilitated the estimation of the net production of $\mathrm{C} 1$ in the photic layer. The slope of the intensities of $\mathrm{C} 1$ to $\mathrm{DO}$ concentrations was $1.08 \pm 0.22 \times 10^{-4}$ R.U. $\mu \mathrm{M}^{-1}$, comparable to $8.9 \pm 1.8 \times 10^{-3} \mu \mathrm{g}$ QS sq. $\mu \mathrm{M}^{-1}$ when converted to an equivalent unit of quinine sulfate (Yamashita and Tanoue, 2008), which reflects the ratio of C1 production to oxygen depletion by microbial respiration. The slope obtained in this study was lower than that determined by the incubation experiments using surface seawater in a coastal upwelling region $\left(2.7 \pm 0.3 \times 10^{-2} \mu \mathrm{g}\right.$ QS sq. $\mu \mathrm{M}$ -1 ; Nieto-Cid et al., 2006). Conversely, the slope found in this study was higher than that of the intensity and AOU observed in intermediate and deep waters in the Pacific Ocean (4.3-4.9 $\times 10^{-3} \mu \mathrm{g}$ QS sq. $\mu \mathrm{M}^{-1}$; Yamashita and Tanoue, 2008; 2.9-3.9 × $10^{-5}$ R.U. $\mu \mathrm{M}^{-1}$; Tanaka et al., 2014, respectively). The production of humic-like FDOM per oxygen in the surface water was likely to be higher than that in the deep ocean.

del Giorgio and Duarte (2002) had estimated the respiration rate in the global photic layer as 3.9-5.1 $\mathrm{Pmol} \mathrm{O}_{2}$ year $^{-1}$, with this value mostly occurring due to bacterial respiration as the respiration rates of protozoa, zooplankton, and vertebrates generally account for less than $10 \%$ of the total respiration in the surface layer (del Giorgio and Duarte, 2002; Robinson and Williams, 2005). When we adopted these respiration rates, the net production rate of $\mathrm{C} 1$ in the global photic layer was calculated as 4.2-5.5 × $10^{17}$ R.U. year ${ }^{-1}$, comparable to $34-45 \times 10^{18} \mu \mathrm{g}$ QS sq. year $^{-1}$. Globally, humic-like FDOM production rates in the mesopelagic (200-1000 m) and abyssal layers (1000 m-bottom) in the oceans were estimated as $12-16$ and $0.74-0.91 \times 10^{18} \mu \mathrm{g}$
QS sq. year ${ }^{-1}$, respectively (Yamashita and Tanoue, 2008). The net production of humic-like FDOM obtained in this study was possibly thrice in the photic layer than in the dark ocean. This estimation implied that the potential production rate of humic-like FDOM in the photic zone was significantly high and approximately $75 \%$ of production in the ocean occurred in the photic layer. Thus, the low fluorescence intensity of humic-like FDOM in the photic layer did not indicate its low production rate but implied a state of equilibrium in its active production and photobleaching.

The active turnover of humic-like FDOM indicated the active formation of various FDOM derivatives after photobleaching. One of the FDOM derivatives is post-FDOM (Omori et al., 2015). Recent studies have suggested that organic matter of bacterial FDOM is mostly stable against light irradiation; however, fluorophore is highly sensitive (Arai et al., 2018). When post-FDOM was persistent to bacterial degradation (Kramer and Herndl, 2004), it could remain and contribute to DOM pool accumulated in the surface layer (Hansell et al., 2012; Hansell, 2013). Humic-like FDOM produced and photobleached in the surface layer possibly plays important roles in the biogeochemical cycle.

\section{CONCLUSION}

In this study, the diurnal variations in the fluorescence intensities of humic-like and tyrosine-like FDOM were demonstrated in incubation experiments using surface seawater. Humiclike $\mathrm{A}$ and $\mathrm{M}$ were observed to increase due to bacterial production during the night and both humic-like and tyrosinelike components decreased due to photobleaching under sunlight exposure during the day. In addition, both humic-like components significantly increased during the day under dark conditions, indicating that they were continuously produced during the day. Especially for humic-like A, same range obtained for TRi and TRd suggested that microbial production and photobleaching were almost in equilibrium, with the intensity of humic-like FDOM in the surface water always being low. Further, using the TRi of humic-like A and global respiration rates, the net production of humic-like FDOM in the global photic layer was estimated to be approximately $75 \%$ of the production in the entire ocean. This estimation indicated a state of equilibrium between the active production and photobleaching of humic-like FDOM. Future studies should examine the relationships between the changes in the fluorescence intensities of humic-like components and DO concentrations in different oceanic areas and seasons to accurately estimate the production of humic-like FDOM in the global surface layer.

\section{DATA AVAILABILITY STATEMENT}

The datasets presented in this study can be found in online repositories. The names of the repository/repositories 
and accession number(s) can be found below: DNA Data Bank of Japan (DDBJ) [accession: DRA010892].

\section{AUTHOR CONTRIBUTIONS}

YO and TH designed the work. AS, SW, YI, and YO conducted the experiments and laboratory analysis. SW, TH, and YO processed the data. YO wrote the manuscript with the help and the inputs of all co-authors. All authors contributed to the article and approved the submitted version.

\section{FUNDING}

This study was financially supported by the Grants-in-Aid (No. $15 \mathrm{~K} 13599,20 \mathrm{~K} 12145$ and 17K12812) from Japan Society for the Promotion of Science.

\section{REFERENCES}

Arai, K., Wada, S., Shimotori, K., Omori, Y., and Hama, T. (2018). Production and degradation of fluorescent dissolved organic matter derived from bacteria. J. Oceanogr. 74, 39-52. doi: 10.1007/s10872-017-0436-y

Bauer, J. E., Williams, P. M., and Druffel, E. R. M. (1992). 14C activity of dissolved organic carbon fractions in the north-central pacific and sargasso sea. Nature 357, 667-670. doi: 10.1038/357667a0

Benner, R., and Amon, R. M. W. (2015). The size-reactivity continuum of major bioelements in the ocean. Ann. Rev. Mar. Sci. 7, 185-205. doi: 10.1146/annurevmarine-010213-135126

Benner, R., and Herndl, G. J. (2011). "Bacterially derived dissolved organic matter in the microbial carbon pump," in Microbial Carbon Pump In The Ocean. Science/AAAS, eds N. Jiao, F. Azam, and S. Sanders (Washington, DC: Washington), 46-48.

Buchan, A., Lecleir, G. R., Gulvik, C. A., and González, J. M. (2014). Master recyclers: features and functions of bacteria associated with phytoplankton blooms. Nat. Publ. Gr. 12, 686-698. doi: 10.1038/nrmicro3326

Caporaso, J. G., Kuczynski, J., Stombaugh, J., Bittinger, K., Bushman, F. D., Costello, E. K., et al. (2010). QIIME allows analysis of high-throughput community sequencing data. Nat. Methods 7, 335-336. doi: 10.1038/nmeth. f.303

Carlson, C. A., and Hansell, D. A. (2015). "DOM sources, sinks, reactivity, and budgets," in Biogeochemistry of Marine Dissolved Organic Matter (Second Edition), eds D. A. Hansell and C. A. Carlson (Boston: Academic Press), 65-126. doi: 10.1016/B978-0-12-405940-5.00 003-0

Catalá, T. S., Reche, I., Fuentes-Lema, A., Romera-Castillo, C., Nieto-Cid, M., and Ortega-Retuerta, E. (2015). Turnover time of fluorescent dissolved organic matter in the dark global ocean. Nat. Commun 6:5986. doi: 10.1038/ ncomms6986

Coble, P. G. (1996). Characterization of marine and terrestrial DOM in seawater using excitation-emission matrix spectroscopy. Mar. Chem. 51, 325-346. doi: 10.1016/0304-4203(95)0006263

del Giorgio, P. A., and Duarte, C. M. (2002). Respiration in the open ocean. Nature 420, 379-384. doi: 10.1038/nature01165

Dittmar, T., and Paeng, J. (2009). A heat-induced molecular signature in marine dissolved organic matter. Nat. Geosci. 2, 175-179. doi: 10.1038/ngeo440

González-Benítez, N., García-Corral, L. S., Morán, X. A. G., Middelburg, J. J., Pizay, M. D., and Gattuso, J. P. (2019). Drivers of microbial carbon fluxes variability in two oligotrophic Mediterranean coastal systems. Sci. Rep. 9:17669. doi: 10.1038/s41598-019-53650-z

Goto, S., Tada, Y., Suzuki, K., and Yamashita, Y. (2017). Production and reutilization of fluorescent dissolved organic matter by a marine bacterial strain, Alteromonas macleodii. Front. Microbiol. 8, 1-10. doi: 10.3389/fmicb. 2017.00507

\section{ACKNOWLEDGMENTS}

We deeply thank the researchers and crews of R/V Shinseimaru on the cruise of 16-03 and the members of Shimoda Marine Research Center, University of Tsukuba, Japan, for their generous assistance in the collection and incubation of water samples. We are grateful to laboratory members of Dr. Inagaki at University of Tsukuba for DNA extraction and PCR procedure. We thank the Chemical Analysis Division, Research Facility Center for Science and Technology, University of Tsukuba, for using their spectrofluorometer.

\section{SUPPLEMENTARY MATERIAL}

The Supplementary Material for this article can be found online at: https://www.frontiersin.org/articles/10.3389/fmars. 2020.589064/full\#supplementary-material

Hansell, D. A. (2013). Recalcitrant dissolved organic carbon fractions. Ann. Rev. Mar. Sci. 5, 421-445. doi: 10.1146/annurev-marine- 120710100757

Hansell, D. A., Carlson, C. A., and Schlitzer, R. (2012). Net removal of major marine dissolved organic carbon fractions in the subsurface ocean. Global Biogeochem. Cycles 26, 1-9. doi: 10.1029/2011GB004069

Hansell, D. A., Carlson, C. A., Repeta, D. J., and Schlitzer, R. (2009). Dissolved organic matter in the ocean a controversy stimulates new insights. Oceanography 22, 202-211. doi: 10.5670/oceanog.2009.109

Hayase, K., and Shinozuka, N. (1995). Vertical distribution of fluorescent organic matter along with AOU and nutrients in the equatorial central pacific. Mar. Chem. 48, 283-290. doi: 10.1016/0304-4203(94)00051-E

Helms, J. R., Stubbins, A., Perdue, E. M., Green, N. W., Chen, H., and Mopper, K. (2013). Photochemical bleaching of oceanic dissolved organic matter and its effect on absorption spectral slope and fluorescence. Mar. Chem. 155, 81-91. doi: 10.1016/j.marchem.2013.05.015

Jiao, N., Herndl, G. J., Hansell, D. A., Benner, R., Kattner, G., Wilhelm, S. W., et al. (2010). Microbial production of recalcitrant dissolved organic matter: long-term carbon storage in the global ocean. Nat. Rev. Microbiol. 8, 593-599. doi: $10.1038 /$ nrmicro2386

Jørgensen, L., Stedmon, C. A., Kragh, T., Markager, S., Middelboe, M., and Søndergaard, M. (2011). Global trends in the fluorescence characteristics and distribution of marine dissolved organic matter. Mar. Chem. 126, 139-148. doi: 10.1016/j.marchem.2011.05.002

Kieber, R. J., Zhou, X., and Mopper, K. (1990). Formation of carbonyl compounds from UV-induced photodegradation of humic substances in natural waters: fate of riverine carbon in the sea. Limnol. Oceanogr. 35, 1503-1515. doi: 10.4319/lo. 1990.35.7.1503

Kirchman, D. L. (2008). Microbial Ecology of the Oceans (Second Edition). New York: Wiley.

Kirchman, D. L., Hill, V., Cottrell, M. T., Gradinger, R., Malmstrom, R. R., and Parker, A. (2009). Standing stocks, production, and respiration of phytoplankton and heterotrophic bacteria in the western arctic ocean. Deep Sea Res. 56, 1237-1248. doi: 10.1016/j.dsr2.2008.10.018

Kowalczuk, P., Tilstone, G. H., Zabłocka, M., Röttgers, R., and Thomas, R. (2013). Composition of dissolved organic matter along an atlantic meridional transect from fluorescence spectroscopy and parallel factor analysis. Mar. Chem. 157, 170-184. doi: 10.1016/j.marchem.2013.10.004

Kramer, G. D., and Herndl, G. J. (2004). Photo- and bioreactivity of chromophoric dissolved organic matter produced by marine bacterioplankton. Aquat. Microb. Ecol. 36, 239-246. doi: 10.3354/ame036239

Kumamoto, Y., Sasano, D., Sato, H., and Matsumoto, K. (2018). "Dissolved oxygen," in Guideline of Ocean Observation, eds S. Otosaka, I. Ueki, D. Sasano, Y. Kumamoto, H. Obata, et al. (Japan: The Oceanographic Society of Japan).

Kuznetsova, A., Brockhoff, P. B., and Christensen, R. H. B. (2017). Lmer test package: tests in linear mixed effects models. J. Stat. Software 82, 1-26. doi: 10.18637/jss.v082.i13 
Lawaetz, A. J., and Stedmon, C. A. (2009). Fluorescence intensity calibration using the raman scatter peak of water. Appl. Spectrosc. 63, 936-940. doi: 10.1366/ 000370209788964548

Lenth, R. V. (2016). Least-squares means: the R package lsmeans. J. Stat. Software 69, 1-33. doi: 10.18637/jss.v069.i01

Lønborg, C., Álvarez-Salgado, X. A., Davidson, K., Martínez-García, S., and Teira, E. (2010). Assessing the microbial bioavailability and degradation rate constants of dissolved organic matter by fluorescence spectroscopy in the coastal upwelling system of the Ría de Vigo. Mar. Chem. 119, 121-129. doi: 10.1016/j.marchem.2010.02.001

Lønborg, C., Yokokawa, T., Herndl, G. J., and Antón Álvarez-Salgado, X. (2015). Production and degradation of fluorescent dissolved organic matter in surface waters of the eastern north Atlantic ocean. Deep. Res. Part I Oceanogr. Res. Pap. 96, 28-37. doi: 10.1016/j.dsr.2014.11.001

Mopper, K., Kieber, D. J., and Stubbins, A. (2015). "Marine photochemistry of organic matter: processes and impacts," in Biogeochemistry of Marine Dissolved Organic Matter (Second Edition), eds D. A. Hansell and C. A. Carlson (Boston: Academic Press), 389-450. doi: 10.1016/B978-0-12-405940-5.00008-X

Mopper, K., Zhou, X., Kieber, R. J., Kieber, D. J., Sikorski, R. J., and Jones, R. D. (1991). Photochemical degradation of dissolved organic carbon and its impact on the oceanic carbon cycle. Nature 353, 60-62. doi: 10.1038/353060a0

Moran, M. A., Sheldon, W. M., and Zepp, R. G. (2000). Carbon loss and optical property changes during long-term photochemical and biological degradation of estuarine dissolved organic matter. Limnol. Oceanogr. 45, 1254-1264. doi: 10.4319/lo.2000.45.6.1254

Morris, R. M., Rappé, M. S., Connon, S. A., Vergin, K. L., Siebold, W. A., Carlson, C. A., et al. (2002). SAR11 clade dominates ocean surface bacterioplankton communities. Nature 420, 806-810. doi: 10.1038/nature01240

Mostofa, K. M. G., Liu, C. Q., Yoshioka, T., Vione, D., Zhang, Y., and Sakugawa, H. (2013). "Fluorescent dissolved organic matter in natural waters," in Photobiogeochemistry of organic matter, eds K. M. G. Mostofa, T. Yoshioka, A. Mottaleb, and D. Vione (Berlin: Springer), 429-559. doi: 10.1007/978-3-64232223-5_6

Murphy, K. R., Stedmon, C. A., Waite, T. D., and Ruiz, G. M. (2008). Distinguishing between terrestrial and autochthonous organic matter sources in marine environments using fluorescence spectroscopy. Mar. Chem. 108, 40-58. doi: 10.1016/j.marchem.2007.10.003

Nagata, T., Fukuda, H., Fukuda, R., and Koike, I. (2000). Bacterioplankton distribution and production in deep pacific waters: large-scale geographic variations and possible coupling with sinking particle fluxes. Limnol. Oceanogr. 45, 426-435. doi: 10.4319/lo.2000.45.2.0426

Nieto-Cid, M., Álvarez-Salgado, X. A., and Pérez, F. F. (2006). Microbial and photochemical reactivity of fluorescent dissolved organic matter in a coastal upwelling system. Limnol. Oceanogr. 51, 1391-1400. doi: 10.4319/lo.2006.51.3. 1391

Obernosterer, I., and Benner, R. (2004). Competition between biological and photochemical processes in the mineralization of dissolved organic carbon. Limnol. Oceanogr. 49, 117-124. doi: 10.4319/lo.2004.49.1.0117

Omori, Y., Hama, T., and Ishii, M. (2015). Photochemical bleaching of fluorescent dissolved organic matter in the subtropical north pacific ocean. Geochem. J. 49, 175-184. doi: 10.2343/geochemj.2.0343

Omori, Y., Hama, T., Ishii, M., and Saito, S. (2010). Relationship between the seasonal change in fluorescent dissolved organic matter and mixed layer depth in the subtropical western north pacific. J. Geophys. Res. Ocean. 115, 1-12. doi: 10.1029/2009JC005526

Porter, K. G., and Feig, Y. S. (1980). The use of DAPI for identifying aquatic microfloral. Limnol. Oceanogr. 25, 943-948. doi: 10.4319/lo.1980.25.5.0943

R Core Team (2018). R: a language and environment for statistical computing. Vienna: R Foundation for Statistical Computing.

Robinson, C., and Williams, P. J. L. B. (2005). "Respiration and its measurement in surface marine waters," in Respiration in aquatic ecosystems, eds P. A. del Giorgio and P. J. L B. Williams (Oxford: Oxford University Press), 147-180. doi: 10.1093/acprof:oso/9780198527084.003.0009

Romera-Castillo, C., Sarmento, H., Álvarez-Salgado, X. A., Gasol, J. M., and Marrasé, C. (2010). Production of chromophoric dissolved organic matter by marine phytoplankton. Limnol. Oceanogr. 55, 446-454. doi: 10.4319/lo.2010.55. 1.0446

Shimotori, K., Omori, Y., and Hama, T. (2009). Bacterial production of marine humic-like fluorescent dissolved organic matter and its biogeochemical importance. Aquat. Microb. Ecol. 58, 55-66. doi: 10.3354/ame01350
Rochelle-Newall, E., and Fisher, T. R. (2002). Production of chromophoric dissolved organic matter fluorescence in marine and estuarine environments: an investigation into the role of phytoplankton. Mar. Chem. 77, 7-21.

Romera-Castillo, C., Sarmento, H., Alvarez-Salgado, X. A. Á., Gasol, J. M., and Marrasé, C. (2011). Net production and consumption of fluorescent colored dissolved organic matter by natural bacterial assemblages growing on marine phytoplankton exudates. Appl. Environ. Microbiol. 77, 7490-7498. doi: 10.1128/ AEM.00200-11

Shimotori, K., Watanabe, K., and Hama, T. (2012). Fluorescence characteristics of humic-like fluorescent dissolved organic matter produced by various taxa of marine bacteria. Aquat. Microb. Ecol. 65, 249-260. doi: 10.3354/ame01552

Stedmon, C. A., and Bro, R. (2008). Characterizing dissolved organic matter fluorescence with parallel factor analysis: a tutorial. Limnol. Oceanogr. Methods 6, 572-579. doi: 10.4319/lom.2008.6.572b

Stedmon, C. A., and Markager, S. (2005). Resolving the variability in dissolved organic matter fluorescence in a temperate estuary and its catchment using PARAFAC analysis. Limnol. Oceanogr. 50, 686-697. doi: 10.4319/lo.2005.50.2. 0686

Stedmon, C. A., and Nelson, N. B. (2015). "The optical properties of dom in the ocean," in Biogeochemistry of Marine Dissolved Organic Matter (Second Edition), eds D. A. Hansell and C. A. Carlson (Boston: Academic Press), 481-508. doi: 10.1016/B978-0-12-405940-5.00010-8

Stedmon, C. A., Markager, S., and Bro, R. (2003). Tracing dissolved organic matter in aquatic environments using a new approach to fluorescence spectroscopy. Mar. Chem. 82, 239-254. doi: 10.1016/S0304-4203(03)0007270

Tanaka, K., Kuma, K., Hamasaki, K., and Yamashita, Y. (2014). Accumulation of humic-like fluorescent dissolved organic matter in the japan sea. Sci. Rep. 4, 1-7. doi: 10.1038/srep05292

Timko, S. A., Maydanov, A., Pittelli, S. L., Conte, M. H., Cooper, W. J., Koch, B. P., et al. (2015). Depth-dependent photodegradation of marine dissolved organic matter. Front. Mar. Sci. 2:66. doi: 10.3389/fmars.2015.00066

Yamashita, Y., and Tanoue, E. (2003). Chemical characterization of protein-like fluorophores in DOM in relation to aromatic amino acids. Mar. Chem. 82, 255-271. doi: 10.1016/S0304-4203(03)0007372

Yamashita, Y., and Tanoue, E. (2008). Production of bio-refractory fluorescent dissolved organic matter in the ocean interior. Nat. Geosci. 1, 579-582. doi: 10.1038/ngeo279

Yamashita, Y., Hashihama, F., Saito, H., Fukuda, H., and Ogawa, H. (2017). Factors controlling the geographical distribution of fluorescent dissolved organic matter in the surface waters of the pacific ocean. Limnol. Oceanogr. 62, 23602374. doi: 10.1002/lno.10570

Yang, F., Song, G., Massicotte, P., Wei, H., and Xie, H. (2020). Depth-resolved photochemical lability of dissolved organic matter in the western tropical pacific ocean. J. Geophys. Res. Biogeosci. 125, 1-14. doi: 10.1029/2019JG005425

Yokokawa, T. (2018). "Direct counting methods of prokaryote and heterotrophic nanoflagellates by epifluorescence microscopy," in Guideline of Ocean Observation, eds S. Otosaka, I. Ueki, D. Sasano, Y. Kumamoto, H. Obata, et al. (Japan: The Oceanographic Society of Japan).

Zhang, C., Dang, H., Azam, F., Benner, R., Legendre, L., Passow, U., et al. (2018). Evolving paradigms in biological carbon cycling in the ocean. Natl. Sci. Rev. 5, 481-499. doi: 10.1093/nsr/nwy074

Zhao, Z., Gonsior, M., Luek, J., Timko, S., Ianiri, H., Hertkorn, N., et al. (2017). Picocyanobacteria and deep-ocean fluorescent dissolved organic matter share similar optical properties. Nat. Commun. 8, 1-10. doi: 10.1038/ncomms15284

Zhou, X., and Mopper, K. (1997). Photochemical production of low-molecularweight carbonyl compounds in seawater and surface microlayer and their air-sea exchange. Mar. Chem. 56, 201-213. doi: 10.1016/S0304-4203(96) 00076-X

Conflict of Interest: The authors declare that the research was conducted in the absence of any commercial or financial relationships that could be construed as a potential conflict of interest.

Copyright (c) 2020 Omori, Saeki, Wada, Inagaki and Hama. This is an open-access article distributed under the terms of the Creative Commons Attribution License (CC BY). The use, distribution or reproduction in other forums is permitted, provided the original author(s) and the copyright owner(s) are credited and that the original publication in this journal is cited, in accordance with accepted academic practice. No use, distribution or reproduction is permitted which does not comply with these terms. 